\title{
Management of Village Funds (ADD) In Development Of Eden Garden In Baumata Barat Village Kecamatan Taebenu Nusa Tenggara Timur
}

\author{
Hidayah Usman \\ Post Graduate, \\ Sebelas Maret University, Surakarta \\ Retno Setyowati \\ Post Graduate, \\ Sebelas Maret University, Surakarta \\ Kusnandar \\ Post Graduate, \\ Sebelas Maret University, Surakarta
}

\begin{abstract}
ABSTRAK
Village fund management (ADD) is a right and obligation that is owned by each region, so that it can be used properly to meet development needs. With the village funds being given to be managed properly, West Baumata Village uses a portion of the village's funds to make or build eden parks. This eden park is a program of the Kupang Regent, which requires that every village in Kupang Regency use village funds to build an eden park, aiming for the eden park to become a place of learning for farmers and so that the farming community can benefit from the Eden Garden. The purpose of this study, to analyze how the management of village funds for the development of the Eden park. The research method used was descriptive qualitative, data collection was carried out by observation, direct interviews, and documentation. Data analysis used includes data collection, data reduction, data presentation, and conclusion drawing. The results of the study show that in managing village funds for the construction of the Eden park, the West Baumata Village Government has carried out each of its activities starting from the planning stage, the implementation stage, and the answer stages in accordance with the applicable regulations.
\end{abstract}

Keywords: Management, Village Funds, Garden of Eden

\section{PRELIMINARY}

According to the Law of the Republic of Indonesia No. 6 of 2014 village funds are funds obtained from the village income and expenditure budget, in the form of regional government assistance. Funds obtained by an area or region are expected to be used correctly in the development process. The assistance provided provides an opportunity for each region to be able to take care of each of its activities independently, with the program from the Kupang Regent so that every village in Kupang Regency especially those who get village funds are expected with village funds that each village can build an eden garden. With the hope that village funds will be used to build the eden park, it will have a greater positive impact on development, namely the farming community can learn how to utilize the materials around them such as agricultural waste and utilize more optimally the land they have. Because according to Job Titu Eki, (2017: 14) the existence of eden parks can provide or produce food 
ingredients so as to make money, display beauty, maintain environmental health, and become a place of learning.

The construction of the eden park launched by the Regent of Kupang is a new program which is the hope that, the development of eden parks in each village area will provide benefits not only in the form of money. Improving the existence of the eden park, the farming community can learn and see firsthand how to manage and utilize what is owned by each individual community, because the essence of development is a process carried out or implemented for a conscious and desired change (Soekanto, 2007: 62) . In the construction of the eden park the management of village funds must be carried out properly and correctly, so that when determining the type of business or what will be implemented it can be used properly at each stage carried out for the construction of the eden garden.

Baumata Barat Village is a village located in the District of Taebenu, Kupang Regency, East Nusa Tenggara, Desa Baumata Barat itself is a village that has many springs. However, there are still many vacant lots that are not managed well, there is an eden park program, the head of the West Baumata village as the leader of the village. Seeing the program being launched has benefits to be developed in Baumata Barat Village, then West Baumata Village participates in utilizing village funds for the eden park development with land area of 1 ha. With the type of komuditi cultivated therein are agriculture and livestock. The reason why this research is needed is because, in the development of utilization and management of village funds originating from the government, which is given trust to every area to manage it. Whether the village funds provided are appropriately used based on the stages that apply or not. So here the purpose of this research is to analyze how the management of village funds for the development of the eden park.

\section{RESEARCH METHODS}

The type of research used is descriptive qualitative research, here the researchers chose to focus the research on:

a. The stages of planning the development of the Eden park.

b. Stages of implementing the eden park development.

c. The first step is the answer to the construction of the Eden Park.

This research was conducted in Baumata Barat Village, Taebenu District, Kupang Regency, East Nusa Tenggara. The researcher chose this location, because based on the initial survey the West Baumata Village had created an eden park with an area of 1 hectare.

The type of data needed to find out how the management of village funds in the eden park development is primary data and secondary data as follows:

a. The primary data that is intended is the farming community that is directly involved in the eden park (Chair of the Farmer Group, Farmer Group Secretary, and Farmer Group Members) then from the village government namely (Village Head and Field Extension).

b. Secondary data in this case is village expenditure budget.

Determination of sample size here uses, Purposive Sampling and Snowball Sampling as according to Arikunto, (2013: 183) for the determination of the sample, the consideration is the data source that is considered most knowledgeable about what is expected by a researcher.

Data collection techniques used to obtain data are as follows:

a. Conduct direct observation of the field, to observe directly and record the symptoms found in the field and maintain data that is not affordable. 
b. Open interviews with resource persons or respondents, so that more information will be explored about what a researcher wants to do with regard to managing village funds for the eden park development.

Analysis of the data used is using qualitative analysis techniques, according to Linclon and Guba in Moleong (2013: 112) which consists of four activities that will be carried out from the beginning to the completion of the activities as follows:
a. Data collection.
b. Data reduction.
c. Data presentation.
d. Draw conclusions.

\section{RESULTS AND DISCUSSION \\ Management of Village Funds for the Construction of the Garden of Eden}

The management of village fund allocation (ADD) for a region must go through stages well and correctly, based on the Minister of Home Affairs Regulation No. 37 of 2007 concerning Guidelines for Village Financial Management Article 20 which is a village financial management unit must go through several stages including 1 Planning Phase 2. Implementation Phase 3. Response Stage. In the management of village funds for the construction of the park eden the steps taken are as follows:

\section{Planning for Village Fund Management for the Construction of the Garden of Eden}

Determination of the type of commudity was carried out between the village head and the eden park coordinator team, who was appointed directly from the Kupang Regent, namely kampung daun. Where the meeting discussed about how much land has been prepared by West Baumata Village for the eden garden, so that the coordinator can go down to the field to see how prepared it is. To then provide outreach to the farming community regarding the land area provided, what kinds of commodities can be cultivated. Based on the results of interviews conducted to Mr. Job as the head of Baumata Barat Village in his residence are as follows:

"The creation of the eden park I invited the coordinating team to attend to discuss, the land area we have and the supporting facilities in the eden park in the form of reservoirs to determine what commodity is feasible to cultivate ..." (Head of West Baumata Village, Mr. Job).

In line with what was explained by the head of the Baumata Barat Village above, the results of interviews conducted to Mr. Rasyid as the eden park coordinating team who gave information on the eden park in Baumata Barat Village were as follows:

"When planning on the land area, making my eden park as the coordinator team. Invited to the village to discuss the land area owned, then what types of commudities are suitable to be cultivated ... "(Eden Park Coordinator Mr. Rasyid).

After discussing with the coordinator team, the village head together with the village apparatus compiled a plan regarding the eden park which was included in the village development plan (RKPdes). In the village development planning stage, hamlet deliberations (Musdus) are held to accommodate the aspirations of each invited farming community. Then the results of the Musdus were brought to the village musyawara (Musdes) to determine the priority scale to be carried out in the development of the eden park, after which the village secretary (Sekdes) prepared a village development plan (Raperdes) which was then discussed together for approval. While at the planning stage a special team was formed, tasked with preparing a village development plan (Rapdes). This is in accordance with the results of interviews 
conducted to the head of Baumata Barat Village, Mr. Job Soleman Nifu on Tuesday, 7, January, 2019 at the Baumata Barat Village office as follows:

"In determining the type of commodity that will be sought, the planning team prepares the village development plan (RPdes). Then it was discussed and agreed upon with the activity supervisory team (TPK) to be established in the construction of the eden park ... "(Head of Baumata Village west of Mr Ayub, Tuesday, 7, January, 2019).

This is also in accordance with the statement of the West Baumata Village Secretary, Ms. Yubliana who conducted interviews in the villages on Tuesday, 9, January, 2019 as follows: "We started planning from the hamlet discussion to listen to input from the community, then brought it to the Village Council (Musdes) to determine the priority scale for village development needs (RKPDes) ..." (Ms. Yubliana on Tuesday, 9, January, 2019).

From the information above, it shows that the people of West Baumata Village are very good when they get an invitation to attend the meeting. Provide input and opinions relating to the eden park, in terms of government transparency West Baumata Village makes posters on display in front of the village office. In order for the public to see the amount of money earned and the amount of money that comes out, according to the results of interviews conducted with the head of West Baumata Village conducted in the village, the Head of West Baumata Village, Tuesday, 7, January, 2019 is as follows:

"Here we as the village government make posters on display in front of the village office, regarding the amount of money and the amount of expenditure used for village development so that the farmers can see the nominal amount obtained by the village ..." (West Baumata Village Chief Job Soleman Nifu, Tuesday, 7, January, 2019).

\section{IMPLEMENTATION OF VILLAGE FUND MANAGEMENT FOR THE DEVELOPMENT OF THE GARDEN OF EDEN}

The implementation of the eden park development, Desa Baumata Barat formed an activity management team (TPK) to carry out activities in the field. The TPK is coordinated directly by the village head, where the TPK is tasked with providing the materials needed by group members. This is in accordance with the statement from the head of Baumata Barat Village, Mr. Job Soleman Nifu, who was interviewed in the village on Tuesday, 7, January, 2019 as follows:

"For activities in the field, we formed an activity management team (TPK). The activity management team (TPK) is directly supervised by myself as the village head where the team is tasked with carrying out, supervising, and reporting on all activities from the work program in the Eden Park. "(West Baumata Village Chief Job Soleman Nifu, Tuesday, 7, January, 2019).

Carrying out the eden park development activities, the farming community is involved in it starting from the fence process to the process of plant maintenance. In accordance with Law No. 6 of 2014 in implementing development funded from village funds (ADD), it involves the community of farmers or group members to self-manage each activity. In using local resources or raw materials and striving to absorb more labor from the local village community, this is in accordance with the statement from the TPK Secretary. Mr. Melki Yanus, who has been consistent with the statements of members of the Eden Garden Group and the Village Head, in the interviews conducted at the village level are as follows:

"For workers in making eden parks, starting from making fences to processing land.

We are prioritized by the people who are members of farmer groups ... "(Chairperson of the TPK, Mr. Melkiyanus, January 6, 2019). 
To meet the implementation needs of the eden park development, according to an explanation from the treasurer of the West Baumata Village, the amount of cash stored in the village treasury is only one million rupiah (Village Treasurer, January 8, 2019). Carrying out eden park development activities, TPK buys the items needed in accordance with the needs of group members. After receiving the goods, the TPK is obliged to submit a letter to the village secretary (village secretary), village head (village head), and development plan (Kup). In order to be able to withdraw money, to spend the needs in the eden park, then the expenditure is entered into the village expenditure archive.

The village treasurer will disburse funds at the order of the village secretary and be approved directly by the village head, later after the money is released the treasurer will hand it over to the coordinator. The coordinator then submits directly to the activity monitoring team (TPK), which manages the West Baumata Village government work program. Carry out all village expenditure activities in the context of implementing village authority, carried out through the village cash account (RKD). All transactions, both village income and expenditure, must be supported by complete and legal evidence and signed by the village head. Treasurer is obliged to account for money through the accountability report, this accountability report is submitted every month to the village head no later than the next 10 months. The village treasurer closes the book at the end of the month in an orderly manner, closing the book is done together with the village head Permendagri article 35 No. 113 of 2014.

The West Baumata Village Government has its own way of carrying out activities, namely by giving full rights to the activity implementing team (TPK). To directly provide goods or needs that have been spent for the needs of members of the eden park group, in order to realize the principle of transparency this is in accordance with the statement from the head of West Baumata Village. The interviewees at his residence are as follows:

"We recommend making a recipient team (TPB), when goods are given to group members. The recipient of the goods must record then the activity supervisory team (TPK) will crosscheck the goods sent, if the community has agreed and there is no difference. It means that the purpose of the community in the implementation is indeed achieved .... "(Head of Baumata Barat Village, 7 January 2019).

The statement from the Village Head above is also in accordance with the statement of one of the members of the Eden park group, Mr Melkiy. The interviewees at his residence are as follows:

"It is true that when there was a work program for making fencing and processing, the community was involved by forming a local committee to cross check. Regarding items received by the local committee in the field ... "(Member of the Bapak Melkiy Eden Park Group).

\section{ACCOUNTABILITY FOR VILLAGE FUND ALLOCATION MANAGEMENT}

The Baumata Barat Village Government in making accountability, has carried out accountability well based on the provisions that have been made. Based on guidelines for using village funds from their publications, through village income and expenditure budgets. This is consistent with the statement from the Head of West Baumata Village interviewed at the village level as follows:

"To implement the principle of accountability and transparency we made a report to be reported to the Bupati, to inform about village fund allocation (ADD) and its use for the community. Posters are displayed in front of the village office, so that residents can find out the amount of ADD obtained by the village and its use ... "(Head of Baumata Barat Village, 7 January 2019). 
The statement from the Head of the West Baumata Village above, was in accordance with the statement from Ms. Kaur of development interviewed at the village hall as follows:

"We are here ordered to make a report, based on an order from the village father to be reported at the end of each year and we make a poster aimed so that the community can see the amount of funds coming out ..." (Mrs. Kaur).

The management of Aloksai dana desa (ADD) for eden park development has been carried out in accordance with regulations made by the government, namely based on Minister of Home Affairs Regulation No. 37 of 2007 concerning Guidelines for Village Financial Management in Article 20. Because village financial management includes planning, implementation, and pertangung answers. Baumata Barat Village uses village funds to meet the needs in the eden park, starting from arranging initial planning regarding the land area needed for the creation of eden parks which then conducts community consultations with farmers. Discussing the need to be agreed upon jointly between the farming community and the village government, then entered into the village budget for the needs of the eden garden area. The implementation of the creation of the Eden Park, using village funds to spend the necessity of making eden parks. Purchases of necessities for eden parks, parties that are given trust are required to show proof of purchase to the village head. In order for the village head to see the conformity of the items bought by the security committee (TPK), after all the activities were completed, the village side made an accountability report. Regarding the use of village funds for village development which was reported to Kabaputen Kupang, so that the Regency checked the extent to which the West Baumata Village used village funds for village development whether it was in accordance with what was given or not.

\section{CONCLUSION}

Village fund management for the eden park development carried out by the West Baumata Village government, has been carried out or implemented based on the procedures and conditions provided. Where from the village government in planning always conduct discussions with the eden park coordinator team to ask about the land area which has the type of commodity that is feasible to be cultivated. At the stage of implementation here the village government forms an implementation team of activities aimed at the implementation, distribution or purchase of necessities in the eden park can be controlled properly. So that when entering at the stage of answer, each member who gets the task can be responsible for giving a good explanation.

\section{THANK-YOU NOTE}

Thank you I say to God the Almighty, has provided safety in research to the writing of this journal. I don't forget to say thank you, to the two counselors who patiently guide giving input and suggestions in this journal.

\section{Book Resources}

\section{BIBLIOGRAPHY}

Arikunto, Suharsimi, (2013). Prosedur Penelitian Suatu Pendekatan Praktik. Jakarta: Pt Rineka Cipta.

Ayub Titu Eki, (2017). Dan Kisah Taman Eden Di Kabupaten Kupang. Smart Cv. Smartekindo.

Moleong, J. Lexi, (2013). Metodologi Penelitian Kualitatif. Bandung: Penerbit PT Remaja Rosdakarya.

Soekanto, Soerjono, (2007). Sosiologi suatu Pengantar. Jakarta: P.T.Raja Grafindo

\section{Legislation}

Undang-Undang Nomor 6 Tahun 2014 Tentang Desa, Lembaran Negara Republik Indonesia Tahun 2014 Nomor 7 , Tambahan Lembaran Negara Nomor 5495.

Undang-undang Peraturan Menteri Dalam Negeri Nomor 37 Tahun 2007 Tentang Pedoman Pengelolaan Keuangan Desa Pada Pasal 20 bahwa Pengelolaan Alokasi Dana Desa (ADD). 